Review Article

\title{
Dental Healthcare Professionals (DHCP) - How Competent are we to Battle the New Foe? The Severe Acute Respiratory Syndrome CoronaVirus-2 (SARS-CoV-2)
}

\section{Hemalatha Ramakrishnan}

Professor (Periodontics), Karpaga Vinayaga Institute of Dental Sciences, Maduranthakantaluk, Chengalpet DT, Tamilnadu, India. DOI: https://doi.org/10.24321/0019.5138.202152

\section{I $\quad \mathbf{N} \quad \mathbf{F} \quad \mathbf{O}$}

\section{Corresponding Author:}

Hemalatha Ramakrishnan, Karpaga Vinayaga Institute of Dental Sciences, Maduranthakantaluk, Chengalpet DT, Tamilnadu, India.

E-mail Id:

hemaarun21@gmail.com

Orcid Id:

https://orcid.org/0000-0002-8547-7718

How to cite this article:

Ramakrishnan H. Dental Healthcare Professionals (DHCP) - How Competent are we to Battle the New Foe? The Severe Acute Respiratory Syndrome CoronaVirus-2 (SARS-CoV-2) .J Commun Dis. 2021;53(3):159-166.

Date of Submission: 2021-08-03

Date of Acceptance: 2021-08-29

\section{$\begin{array}{llllllll}\mathbf{A} & \mathbf{B} & \mathbf{S} & \mathbf{T} & \mathbf{R} & \mathbf{A} & \mathbf{C} & \mathbf{T}\end{array}$}

The outbreak of a pneumonia like disease was reported in China towards the end of 2019. It was later found that, a novel Corona Virus (nCoV) was the causative agent. In January 2020, China shared the genomic sequence of this virus, which was similar to Severe Acute Respiratory Syndrome Corona Virus (SARS-CoV), and Middle East Respiratory Syndrome Corona Virus (MERS-CoV). This virus was named as Severe Acute Respiratory Syndrome Corona Virus-2 (SARS-CoV-2) and the pneumonia caused by it was called as Corona Virus Disease 2019 (COVID-19). The World Health Organization (WHO) declared COVID-19 to be a pandemic owing to the uncontrolled spread and the threat caused by the virus. Thereafter, the rapid spread of COVID-19, keeps continuing to cause chaos and catastrophe to mankind. Though mortality ranges about $1-3 \%$, with mild variations worldwide, the rate of infectivity is much higher than SARS-CoV. The understanding on the pathogenesis of this virus remains mysterious and unclear. As frontline warriors against the COVID-19 battle, Healthcare Professionals, are more susceptible to succumb to this disease. Dental healthcare professionals (DHCP), owing to a closer contact with patients, during dental operating procedures are at a higher risk of acquiring and spreading the infection due to increased aerosol production. This review, gives an insight about the structure, transmission characteristics of SARS-CoV-2 and the possibility of spread through aerosol. It also highlights the precautions and safety measures that need to be followed within the dental operatory setting.

Keywords: SARS-CoV-2, COVID-19, Aerosol Transmission, DHCP

\section{Introduction}

At the close of 2019, on 31st December, China informed the World Health Organization (WHO) office in its country about the outbreak of pneumonia of unknown cause, detected in the city of Wuhan, in Hubai province, China, among the vendors in Huanan sea food market. A novel Corona Virus (nCoV) was confirmed to be the etiologic agent of the pneumonia like disease during the 1st week of January, 
following which China shared the genomic sequence of the causative virus. The viral genome sequence was closely related to the other zoonotic viruses namely, Severe Acute Respiratory Syndrome Corona Virus (SARS-CoV), and Middle East Respiratory Syndrome Corona Virus (MERS-CoV) that hit mankind in the beginning of 21st century. On 13th January, the first case of this novel Corona Virus (nCoV) outside China was reported in Thailand, following which the spread started worldwide as fast as a forest wildfire. The Virus, later was provisionally named as the Severe Acute Respiratory Syndrome Corona Virus 2 (SARS-CoV-2) by the International Virus Classification Commission. ${ }^{1}$ The Pneumonia induced by SARS-CoV-2 was named as Corona Virus Disease 2019 (COVID 19) on 11th February 2020 by WHO. Making an assessment about the alarming levels of the spread and severity, on 11th March 2020, WHO declared COVID-19 as a Pandemic. Till date, as medicinal remedy remains an unanswered question, the deadly COVID-19 continues to take a heavy toll on human lives. This review aims at giving an insight about the properties of SARS-CoV-2, and as healthcare professionals, the level of risk, a dental surgeon need to face, while treating patients, and the need to follow proper precautions in a dental setting to tide over the crisis of COVID-19 and win the battle against it.

\section{SARS-CoV-2 Structure and Classification}

About four different groups of corona viruses are identified so far. This includes Alpha coronavirus ( $\alpha-\mathrm{CoV})$, Beta corona virus ( $\beta-\mathrm{CoV})$, Gamma corona virus $(\gamma-\mathrm{CoV})$ and Delta coronavirus $(\delta-\mathrm{CoV}) .^{2,3}$ Coronaviruses are spherical in shape with a diameter of $125 \mathrm{~nm} .4,5$ The club shaped spikes seen on the surface of the virus gives the appearance of solar corona, hence the name Corona Virus. The viral core contains helically symmetrical nucleo-capsid, surrounded by an envelope, which is uncommon to RNA viruses. The largest genome for RNA viruses is seen in Corona Virus. The genomic sequencing of SARS-CoV 2 shows about $79 \%$ similarity to SARS-CoV and $50 \%$ similarity to MERS-CoV. SARS-CoV 2 belongs to the genus beta coronavirus and subgenus sarbecovirus. ${ }^{6}$

\section{Possible Enzootic Origin to Zoonotic Transmission}

SARS-CoV is supposed to have its origination from the Chinese horse-shoe bat, as these bats contain SARS related CoV sequence and showed serologic evidence of previous exposure to related corona virus. ${ }^{7,8}$ The presence of an intermediate host is highly suspected in the transfer of this virus to humans. The intermediate host for SARS-CoVs were Civet cats and for MERS-CoV, The Dromedary Camels. SARS-CoV-2 shows $88 \%$ homology to two bat derived SARSCoV, namely SL-CoVZC45 and SL-CoVZXC2.The receptor that SARS-CoV makes use of to bind to the human cell is the Angiotensin Converting Enzyme-2 (ACE-2). In binding to human cells, SARS-CoV-2 express a similar receptor as the
SARS-COV, the Angiotensin Converting Enzyme-2 (ACE-2).

\section{Animal to Human Transmission}

Birds and animals were the earlier species primarily infected by Corona Viruses (CoVs). Some CoVs were originally enzootic infections, but then, they have crossed animalhuman species barrier to cause zoonotic disease in humans.

\section{Human to Human Transmission}

- i) SARS-CoV: Though SARS-CoV spread through direct contact and droplet from infected individuals, the outbreak was limited to the health settings and household and that the transmission of SARS-CoV was inefficient ${ }^{9}$

- $\quad$ ii) SARS-CoV-2: The most common mode of transmission of SARS-CoV-2 is through respiratory droplets from symptomatic patients, with the droplet size ranging from $5 \mu \mathrm{m}$ to $10 \mu \mathrm{m} .10,11$ Transmission can also occur during the incubation period, when the patient is asymptomatic

\section{Pathogenesis}

SARS-CoV-2 virus is likely to bind to the epithelial cells in the nasal cavity and replicate thereafter. The glycoprotein (S glycoprotein) on the spikes of SARS-CoV-2 plays an important role in attaching the virus to the host cells. SARS-CoV-2 makes use of the Angiotensin Converting Enzyme-2 receptor (ACE-2) to bind human cells just as SARS-CoV.12As ACE receptor containing cells are seen in abundance in respiratory tract and epithelial cells of salivary glands, these structures become the main targets of SARS-CoV-2 infection. Respiratory tract and intestinal cells are the primary replication sites of Coronaviruses causing pathologic changes in these respective cell types.13 SARSCoV-2 is a virus, which still needs a better understanding about its pathogenic mechanisms.

\section{Clinical Manifestations of COVID- 19}

Fever is the most common symptom, which is seen in about $97 \%$ of patients, whereas the other symptoms include cough, dyspnea, myalgia and fatigue. ${ }^{14,15}$ Pneumonia is another common manifestation, which is seen in the chest $\mathrm{x}$-ray/chest $\mathrm{CT}$ as interstitial changes and multiple small patches in the peripheral areas of lung.

In severe cases, Acute Respiratory Distress Syndrome (ARDS), acidosis, renal failure, cardiac shock followed by death may occur. ${ }^{16,17}$ Poor prognosis is expected in patients with co-morbidities like Diabetes Mellitus, Hypertension or any other Systemic Illness. A clinical study showed that the survival time of SARS-CoV-2 was significantly longer and that the respiratory samples showed heavy viral load in patients with severe illness, when compared to patients with mild symptoms. 
Incubation Period: The incubation period ranges from 215 days, with the average of 5 days. The patient is highly infectious during the initial stage of infection, when the symptoms are mild. ${ }^{18-22}$ This characteristic feature of SARSCoV-2 differentiates it from SARS-CoV, as in the former, replication of the virus is accelerated early in the upper respiratory tract. ${ }^{23} \mathrm{High}$ viral load of SARS- CoV-2 is reported in the saliva of COVID-19 patients.

\section{Health Workers and COVID-19}

Undoubtedly, healthcare workers, who are serving their best in the battle against SARS-CoV-2are at a higher risk of acquiring COVID-19 at any point of time, regardless of the amount of viral exposure. ${ }^{24}$ In a case-control study conducted by Seto et al 2003, among 241 non-infected and 13 SARS infected staff, the results of the study conveyed that, droplets and hand played an important role in the spread of SARS-CoV. He concluded that face mask and hand hygiene are important part of infection control measures. ${ }^{25}$

\section{Evidence of COVID- 19 Spread in Hospital Setting}

Guo ZD et al. conducted a study in a COVID-19 specialized hospital, with a total of 49 COVID 19 patients, with about 15 patients in Intensive Care Unit (ICU) and 24 patients in the general ward. ${ }^{26,27}$ Both aerosol and surface samples were collected from ICU and General Ward. It was found that, samples collected from ICU showed more positive cases in aerosol and surface compared to the General Ward. This implies that more stringent and meticulous infection control protocol has to be followed in ICU. A Wuhan based research says that $50 \%$ of samples taken from the soles of shoes of ICU staff, tested positive for COVID-19. The shoes of healthcare workers and the floor have proven to be important hotspots of SARS-CoV-2. A study shows that sampling from the shoe of a healthcare tested positive, while Personal Protective Barrier (PPE) sample tested negative. ${ }^{27}$ These inferences, insist the importance of wearing disposable shoe cover or the disinfection of soles of the shoes, as part of Infection Control Protocol (ICP).

\section{Potential of Aerosols to Spread SARS-CoV-2}

Though, the main route of transmission of SARS-CoV-2 is through respiratory droplets and close contact, ${ }^{28}$ the possibility of transmission of SARS-CoV-2 through aerosol and fomite is being investigated. ${ }^{29} \mathrm{It}$ is the novelty of SARSCoV-2 that makes our understanding mysterious and unclear about its transmission dynamics. Various studies have investigated the survival of SARS-CoV-2 in aerosol.

Current data supports the evidence that airborne spread of infected droplets could spread at a distance of more than two meters (6 feet) from one person to another. It was postulated as early as in 1950 s by William Firth that droplet nuclei are small and remain suspended in air for a longer period with retained infectivity.
Morawska L, Cao J has put forward that viral content could diffuse as far as 10 meters from the source of emission, causing aerosol transmission. ${ }^{30}$

Liu et al investigated the aerodynamics of SARS-COV-2 at a hospital, in Wuhan, China. ${ }^{31}$ It was found that in the PPE removal room for medical staff, high levels of SARS-CoV-2 virus RNA was observed. Good ventilation and meticulous follow up of Sterilization Protocol reduced the aerosol concentration of SARS-CoV-2 viral RNA.

Santarpia JL et al. in his study, says that SARS-CoV-2 were detected in aerosol samples collected at Nebraska University Hospital. ${ }^{32}$

Van Doremalen $\mathrm{N}$ et al. conducted a study to assess the stability and viability of SARS-COV-2 and compare with that of SARS-CoV. ${ }^{33}$ The survival time of SARS-CoV 2 lasted as long as 4 hours to 72 hours. It was found that the stability and viability of the virus decreased over time. Plastic surfaces retained the virus for a longer period than cardboard and copper surface. Both SARS-CoV- 2 and SARS-CoV showed similarities in stability and viability in aerosol and different surfaces. ${ }^{34}$

These are some of the studies that tell us about the aerosol survival and stability of SARS-CoV-2 in the hospital setting. These conclusions give us an inference that aerosol transmission has to be considered as an important pathway of SARS-CoV-2 contamination. ${ }^{35}$

So, it is important to follow a proper and prompt Infection Control Protocol in the clinical settings to limit aerosol associated risk of COVID-19 spread. Implementation of universal mask wearing policies and increasing the number of PCR based tests on staff and patients would be some of the important measures to contain COVID-19 spread in health care settings.

\section{Dental Healthcare Professionals and COVID- 19}

\section{Dental Consultation}

Dental Health Care Professionals (DHCPs) are one of the most vulnerable group of people to succumb to this pandemic, owing to the close contact with the patient at the time of dental treatment procedures. So, dentists need to be precautious while handling the patient and follow a proper Infection Control Protocol to prevent the spread of SARS-CoV-2.

A brief history has to be taken from the patient before proceeding to dental consultation or procedure. The interview must highlight questions on the recent past (within the last 2 weeks) of the patient that would help us identify the possibilities of the patient having acquired SARS-CoV-2.

- Does the patient have any history of travel to foreign 
countries, currently affected by the COVID-19 pandemic? Recent history of fever, cough, breathlessness or any other respiratory illness? ${ }^{36}$

- Any close contact with SARS-CoV-2 patient?

- Any systemic illness like diabetes mellitus, hypertension, asthma or any other illness currently under treatment?

- Any recent visit to crowded places/on a pilgrimage tour? ${ }^{37}$

If the answers provided by the patient are favourable to the dentist with "NO" to all the above questions, then the he may proceed with consultation/procedure with proper following of Infection Control Protocol. A "YES" to any of these questions, then he may need to reconsider about further treatment, until the dentist's doubts on COVID 19 are completely cleared.

It is always advisable to check the body temperature of every other patient within the dental clinic with the help of Infrared forehead thermometer. In COVID-19 hotspots, it is safer to address only dental emergencies, and postpone elective dental procedures. A telephonic consultation with prescription of required medicines would be a more appreciable option.

Uncontrolled bleeding following extraction or any other aetiology of dental origin, cellulitis/diffuse extra oral swelling of dentoalveolar origin, or any other trauma of facial bones interfering patient's airway are considered as dental emergencies according the American Dental Association. ${ }^{38}$

\section{Possible Routes of Transmission of SARS-CoV-2 to Dental Health Care Professionals}

Within the dental operatory room, at the time of dental procedure, direct exposure to the infected respiratory droplets may transmit infection. Indirect contact through inanimate surfaces, contaminated instruments and accidental injury from sharp instruments may also transmit infection. A person talking or coughing without mask can propel infected droplets.39-43 High speed dental operatory devices like aerator hand pieces can generate enormous aerosol spilling into the surroundings containing the potentially infected patient's blood, saliva and mucus. The suspended aerosol is a risk factor, which might harbour SARS-CoV-2. These are some of the ways of dentists acquiring SARS-CoV-2 and cross infecting the same to the patients as well.

\section{Precautions to be taken at the Time of Dental Operatory Procedures}

A poster display or an audio-visual aid at the reception of the dental clinic portraying the precautionary measures on COVID-19 and instructions that need to be followed by the patient within the dental clinic would be more appreciable and receptive by the patients than just verbal commands.
The display must include points highlighting the importance of social distancing, cough etiquette and proper disposal of contaminated waste in the trash. Besides enlightening the patients about COVID 19 precautions, it is as well important to educate the reception Personnel about the hand hygiene i.e., need for frequent hand washing and use of hand sterilizer as and when required, use of face mask and to reinforce the same on the visitors.

In a way to limit SARS-CoV-2 spread, use of extra oral radiographs like Orthopantomogram (OPG) would be a better alternative to Intraoral Periapical Radiograph (IOPA), as in the later, in addition to unwanted saliva induction, we may need to contact patient's saliva, with unnecessary triggering of cough. ${ }^{44}$

Use of $0.5 \%-1 \%$ Hydrogen Peroxide and $0.2 \%$ Povidone lodine, as pre-procedural mouth rinse, owing to their effervescent and powerful microbicidal action respectively, would prove effective in reducing the viral load of SARSCoV-2 in saliva. ${ }^{45}$

Use of N-95 masks is highly recommended for aerosol generating procedures. ${ }^{46,47}$ The procedure room should have adequate ventilation with appropriate sterilization and disinfection to contain SARSCoV-2 RNA in aerosols. It is advisable to leave the dental operating room for a while, immediately following the procedure, with doors and windows left open to ensure fresh air circulation to avoid aerosol contamination. Use of an exhaust blower would be beneficial to extract contaminated air out.

Unnecessary and unwanted touching of inanimate surfaces with in the working environment has to be avoided, as they might be a potential reservoir of SARS-CoV- 2. It was found that the SARS-CoV-2 survived on inanimate surfaces as long as 96 hours, thereby providing opportunity for nosocomial spread. ${ }^{48,49}$ UV irradiation effectively inactivates SARS-CoV-2 on inanimate surfaces.

Dental surgeon as well as Dental Assistants need to follow meticulous hand hygiene, following the prescribed steps for hand washing, as many times as possible before and after the dental operatory procedure.

As most of the dental procedures involve aerosol generation, use of hand instruments is advisable. Use of spoon excavators, in caries removal as an alternative to high speed aerator hand piece, handscalers to ultrasonic would be a preferred choice in the time of COVID-19 crisis. Contaminated material containing patient's body secretions like blood, saliva soaked cotton, and gauze has to be disposed with utmost care with proper instructions of biomedical waste disposal.

\section{Sterilization and Disinfection}

Common disinfectants like sodium hypochlorite, hydrogen 
peroxide, when used in appropriate concentrations prove to be worthwhile microbicidal agents in inactivating coronaviruses. ${ }^{50}$

Rabenau HF et al. conducted a study, at the time of outbreak of Severe Acute Respiratory Syndrome (SARS), where disinfectants were investigated against SARS coronavirus (SARS-CoV). Four hand rubs namely Sterillium based on 45\% Isopropanol, 30\% n-Propanol and 0.2\% Mecetronium disulphate; Sterilium Virugard based on $80 \%$ ethanol; Sterillium gel, based on $85 \%$ ethanol were tested at 30 seconds. Three surface disinfectants based on Benzalkonium Chloride and Lauryl amine, Benzalkonium chloride, Glutaraldehyde and Didecyldimonium chloride were also tested at a concentration of $0.5 \%$ for 30 minutes and 60 minutes. SARS-CoV was inactivated below the detection level (reduction factor $>4$ ) with all the preparations. It was found that many commonly used disinfectants easily inactivated SARS-CoV. He also showed that SARS-CoV retained its infectivity till 6 days and it took 9 days to completely dry. ${ }^{51}$

Studies show that alcohol based disinfectants are immediate in action and are highly microbicidal..$^{52}$ It kills a variety of viruses ranging from enveloped virus such as Orthopox virus53, Influenza A virus, Herpes Simplex Virus 1 and 2,54 Hepatitis B Virus55-57and HIV. ${ }^{58,59}$ So, in this line, alcohol based hand rubs must be effective in preventing SARSCoV-2 transmission.

\section{Conclusion}

To tide over the current COVID-19 crisis, it is indispensable to follow a prudent and meticulous Infection Control Protocol, not only in the interest of patient's safety, but also to ensure the welfare of Dental Health Care Professionals (DHCPs) as well. An increased number of RT-PCR based test would help curtail the spread of SARS-CoV2. Let us hope for the best, for the dawn of a day, when mankind would have overtaken this invisible enemy, and eternally won the battle, brimming with joy of victory. Until then, let us be judicious during these trying times, join hands in unison, and extend our co-operation to the society by all possible means, as responsible individuals to get rid of COVID-19 forever.

\section{Role of Funding Source: None \\ Conflict of Interest: None}

\section{References}

1. Coronaviridae Study Group of the International Committee on Taxonomy of Viruses. The species severe acute respiratory syndrome- related coronavirus: classifying 2019-nCoV and naming it SARS-CoV-2. Nat Microbiol. 2020 Apr;5(4):536-44. [PubMed] [Google Scholar]
2. Coronaviridae. In: van Regenmortel MHV, Fauquet CM, DHL B, Carstens EB, Estes MK, Lemon SM, Maniloff J, Mayo MA, McGeoch DJ, Pringle CR, Wickner RB. Editors. Virus taxonomy: classification and nomenclature of viruses seventh report of the international committee on taxonomy of viruses. San Diego: Academic Press. 2000. p. 835-49. [Google Scholar]

3. Woo PC, Lau SK, Lam CSF, Lau CCY, Tsang AKL, Lau JHN, Bai R, Teng JLL, Tsang CCC, Wang M, Zheng B-J, Chan $\mathrm{K}-\mathrm{H}$, Yuen K-Y. Discovery of seven novel mammalian and avian coronaviruses in the genus deltacoronavirus supports bat coronaviruses as the gene source of alphacoronavirus and betacoronavirus and avian coronaviruses as the gene source of gammacoronavirus and deltacoronavirus. J Virol. 2012 Apr;86(7):39954008. [PubMed] [Google Scholar]

4. Barcena M, Oostergetel GT, Bartelink W, Faas FGA, Verkleij A, Rottier PJM, Koster AJ, Bosch BJ. Cryoelectron tomography of mouse hepatitis virus: Insights into the structure of the coronavirion. Proc Natl Acad Sci U S A. 2009 Jan;106(2):582-7. [PubMed] [Google Scholar]

5. Neuman BW, Adair BD, Yoshioka C, Quispe JD, Orca G, Kuhn P, Milligan RA, Yeager M, Buchmeier MJ. Supramolecular architecture of severe acute respiratory syndrome coronavirus revealed by electron cryomicroscopy. J Virol. 2006 Aug;80(16):7918-28. [PubMed] [Google Scholar]

6. Roujian L, Xiang Z, Juan L, Niu P, Yang B, Wu H, Wang W, Song $H$, Huang B, Zhu N, Bi Y, Ma X, Zhan F, Wang L, Hu T, Zhou H, Hu Z, Zhou W, Zhao L, Chen J, Meng Y, Wang J, Lin Y, Yuan J, Xie Z, Ma J, Liu WJ, Wang D, Xu W, Holmes EC, Gao GF, Wu G, Chen W, Shi W, Tan W. Genomic characterisation and epidemiology of 2019 novel coronavirus: implications for virus origins and receptor binding. Lancet. 2020 Feb;395(10224):56574.[PubMed] [Google Scholar]

7. Lau SKP, Woo PCY, Li KSM, Huang Y, Tsoi H-W, Wong BHL, Wong SSY, Leung S-Y, Chan K-H, Yuen K-Y. Severe acute respiratory syndrome coronavirus- like virus in Chinese horseshoe bats. Proc Natl Acad Sci U S A. 2005 Sep;102(39):14040-5. [PubMed] [Google Scholar]

8. Li W, Shi Z, Yu M, Ren W, Smith C, Epstein JH, Wang $\mathrm{H}$, Crameri G, Hu Z, Zhang H, Zhang J, McEachern J, Field H, Daszak P, Eaton BT, Zhang S, Wang L-F. Bats are natural reservoirs of SARS- like coronaviruses. Science. 2005 Oct;310(5748):676-9. [PubMed] [Google Scholar]

9. Peiris JS, Yuen KY, Osterhaus AD, Stohr K. The severe acute respiratory syndrome. N Engl J Med. 2003 Dec;349(25):2431-41. [PubMed] [Google Scholar]

10. Duguid JP. The size and the duration of air-carriage of respiratory droplets and droplet-nuclei. J Hyg (Lond). 1946 Sep;44(6):471-9. [PubMed] [Google Scholar] 
11. Morawska L, Johnson GR, Ristovski ZD, Hargreaves M, Mengersen K, Corbett S, Chao CYH, Lid D, Katoshevski D. Size distribution and sites of origin of droplets expelled from the human respiratory tract during expiratory activities. J. Aerosol Sci. 2009;40:256-69. [Google Scholar]

12. Letko MC, Munster V. Functional assessment of cell entry and receptor usage for lineage $B$ $\beta$-coronaviruses, including 2019-nCoV. bioRxiv. 2020 Jan;2020.01.22.915660. [PubMed] [Google Scholar]

13. Fields BN, Knipe DM, Howley PM (1996) Fields virology. 3rd edition. Lippincott-Raven Publishers, Philadelphia.

14. Chen N, Zhou M, Dong X, Qu J, Gong F, Han Y, Qiu Y, Wang J, Liu Y, Wei Y, Xia J, Yu T, Zhang X, Zhang L. Epidemiological and clinical characteristics of 99 cases of 2019 novel coronavirus pneumonia in Wuhan, China: a descriptive study. Lancet. 2020 Feb;395(10223):50713. [PubMed] [Google Scholar]

15. Huang C, Wang Y, Li X, Ren L, Zhao J, Hu Y, Zhang L, Fan G, Xu J, Gu X, Cheng Z, Yu T, Xia J, Wei Y, Wu W, Xie X, Yin W, Li H, Liu M, Xiao Y, Gao H, Guo L, Xie J, Wang G, Jiang R, Gao Z, Jin Q, Wang J, Cao B. Clinical features of patients infected with 2019 novel coronavirus in Wuhan, China. Lancet. 2020 Feb;395(10223):497-506. [PubMed] [Google Scholar]

16. Chen Z-M, Fu J-F, Shu Q, Chen Y-H, Hua C-Z, Li F-B, Lin $R$, Tang L-F, Wang T-L, Wang W, Wang Y-S, Xu W-Z, Yang Z-H, Ye S, Yuan T-M, Zhang C-M, Zhang Y-Y. Diagnosis and treatment recommendations for pediatric respiratory infection caused by the 2019 novel coronavirus. World J Pediatr. 2020 Jun;16(3):240-6. [PubMed] [Google Scholar]

17. Chan JF-W, Yuan S, Kok K-H, To KK-W, Chu H, Yang J, Xing F, Liu J, Yip CC-Y, Poon RW-S, Tsoi H-W, Lo SK-F, Chan KH, Poon VK-M, Chan W-M, Daniel IPJ, Cai J-P, Cheng VC-C, Chen H, Hui CK-M, Yuen K-Y. A familial cluster of pneumonia associated with the 2019 novel coronavirus indicating person-to-person transmission: a study of a family cluster. Lancet. 2020 Feb;395(10223):514-23. [PubMed] [Google Scholar]

18. To KK-W, Tsang OT-Y, Leung W-S, Tam AR, Wu T-C, Lung DC, Yip CC-Y, Cai JP, Chan JM-C, Chik TS-H, Lau DP-L, Choi CY-C, Chen L-L, Chan W-M, Chan KH, Daniel IPJ, Ng AC-K, Poon RW-S, Luo C-T, Cheng VC-C, Chan JF-W, Hung IF-N, Chen Z, Chen H, Yuen K-Y. Temporal profiles of viral load in posterior oropharyngeal saliva samples and serum antibody responses during infection by SARS-CoV-2: an observational cohort study. Lancet Infect Dis. 2020 May;20(5):565-74. [PubMed] [Google Scholar]

19. Zou L, Ruan F, Huang $M$, Liang L, Huang $H$, Hong Z, Yu J, Kang $\mathrm{M}$, Song $\mathrm{Y}$, Xia J, Guo Q, Song T, He J, Yen H-L, Peiris $\mathrm{M}, \mathrm{Wu}$ J. SARS-CoV-2 viral load in upper respiratory specimens of infected patients. N Engl J Med. 2020 Mar;382(12):1177-9. [PubMed] [Google Scholar]

20. Bai Y, Yao L, Wei T, Tian F, Jin D-Y, Chen L, Wang $M$. Presumed asymptomatic carrier transmission of COVID-19. JAMA. 2020 Apr;323(14):1406-7. [PubMed] [Google Scholar]

21. Zhang J, Litvinova $M$, Wang $W$, Wang $Y$, Deng $X$, Chen $X$, Li M, Zheng W, Yi L, Chen X, Wu Q, Liang Y, Wang $X$, Yang J, Sun K, Longini Jr YM, Halloran ME, Wu P, Cowling BJ, Merler S, Viboud C, Vespignani A, Ajelli M, Yu H. Evolving epidemiology and transmission dynamics of coronavirus disease 2019 outside Hubei province, China: a descriptive and modelling study. Lancet Infect Dis. 2020 Jul;20(7):793-802. [PubMed] [Google Scholar]

22. van Doremalen N, Bushmaker T, Morris DH, Holbrook MG, Gamble A, Williamson BN, Tamin A, Harcourt JL, Thornburg NJ, Gerber SI, Lloyd-Smith JO, de Wit E, Munster VJ. Aerosol and Surface Stability of SARSCoV-2 as Compared with SARS-CoV-1. N Engl J Med. 2020 Apr;382(16):1564-7. [PubMed] [Google Scholar]

23. Wölfel R, Corman VM, Guggemos $W$, Seilmaier $M$, Zange S, Müller MA, Niemeyer D, Jones TC, Vollmar $P$, Rothe $C$, Hoelscher M, Bleicker T, Brünink S, Schneider J, Ehmann R, Zwirglmaier K, Drosten C, Wendtner C. Virological assessment of hospitalized patients with COVID-2019. Nature. 2020 May;581(7809):465-9. [PubMed] [Google Scholar]

24. Ho KY, Singh KS, Habib AG, Ong BK, Lim TK, Ooi EE, Sil BK, Ling A-E, Bai XL, Tambyah PA. Mild illness associated with severe acute respiratory syndrome coronavirus infections: lessons from a prospective seroepidemiologic study of healthcare workers in a teaching hospital in Singapore. J Infect Dis. 2004 Feb;189(4):642-7. [PubMed] [Google Scholar]

25. Seto WH, Tsang D, Yung RWH, Ching TY, Ng TK, Ho M, Ho LM, Peiris JSM, Advisors of Expert SARS group of Hospital Authority. Effectiveness of precautions against droplets and contact in prevention of nosocomial transmission of severe acute respiratory syn- drome (SARS). Lancet. 2003 May;361(9368):1519-20. [PubMed] [Google Scholar]

26. Guo ZD, Wang ZY, Zhang SF, Li X, Li L, Li C, Cui Y, Fu R-B, Dong Y-Z, Chi X-Y, Zhang M-Y, Liu K, Cao C, Liu B, Zhang K, Gao Y-W, Lu B, Chen W. Aerosol and surface distribution of severe acute respiratory syndrome coronavirus 2 in hospital wards, Wuhan, China, 2020. Emerg Infect Dis. 2020 Jul;26(7):1583-91. [PubMed] [Google Scholar]

27. Ong SW, Tan YK, Chia PY, Lee TH, Ng OT, Wong MS, Marimuthu K. Air, surface environmental, and personal protective equipment contamination by severe acute respiratory syndrome coronavirus 2 (SARS-CoV-2) from a symptomatic patient. JAMA. 2020 Apr;323(16):1610- 


\section{2. [PubMed] [Google Scholar]}

28. World Health Organization. Coronavirus disease (COVID-2019) situation reports. Geneva: WHO, 2020.

29. Cai J, Sun W, Huang J, Gamber M, Wu J, He G. Indirect virus transmission in cluster of COVID-19 cases, Wenzhou, China, 2020. Emerg Infect Dis. 2020 Jun;26(6):1343-5. [PubMed] [Google Scholar]

30. Morawska L, Cao J. Airborne transmission of SARSCoV-2: The world should face the reality. Environ Int. 2020 Jun;139:105730. [PubMed] [Google Scholar]

31. Liu Y, Ning Z, Chen Y, Guo M, Liu Y, Gali NK, Sun L, Duan Y, Cai J, Westerdahl D, Liu X, Xu K, Ho K-F, Kan H, Fu $\mathrm{Q}$, Lan K. Aerodynamic analysis of SARS-CoV-2 in two Wuhan hospitals. Nature. 2020 Jun;582(7813):557-60. [PubMed] [Google Scholar]

32. Santarpia JL, Rivera DN, Herrera V, Morwitzer JM, Creager H, Santarpia GW, Crown KK, Brett-Major D, Schnaubelt E, Broadhurst MJ, Lawler JV, Lowe JJ. Transmission potential of SARS-CoV-2 in viral shedding observed at the University of Nebraska Medical Center. medRxiv, 2020.

33. van Doremalen $\mathrm{N}$, Bushmaker $\mathrm{T}$, Morris $\mathrm{DH}$, Holbrook MG, Gamble A, Williamson BN, Tamin A, Harcourt JL, Thornburg NJ, Gerber SI, Lloyd-Smith JO, de Wit E, Munster VJ. Aerosol and surface stability of SARSCoV-2 as compared with SARS-CoV-1. N Engl J Med 2020;382:1564e7. [PubMed] [Google Scholar]

34. Rabenau HF, Kampf G, Cinatl J, Doerr HW. Efficacy of various disinfectants against SARS coronavirus. J Hosp Infect. 2005 Oct;61(2):107-11. [PubMed] [Google Scholar]

35. Milling A, Kehr R, Wulf A, Smalla K. Survival of bacteria on wood and plastic particles: Dependence on wood species and environmental conditions. Holzforschung. 2005;59:72-81. [Google Scholar]

36. Prasad S, Potdar V, Cherian S, Abraham P, Basu A. Transmission electron microscopy imaging of SARSCoV-2. Indian J Med Res. 2020 Feb \& Mar;151(2 \& 3):241-3. [PubMed] [Google Scholar]

37. Peng $X, X u X$, Li $Y$, Cheng L, Zhou X, Ren B. Transmission routes of 2019-nCoV and controls in dental practice. Int J Oral Sci. 2020 Mar;12(1):9. [PubMed] [Google Scholar]

38. Mihailovic B, Miladinovic M, Vujicic B. Telemedicine in dentistry (teledentistry). Advances in Telemedicine: Applications in Various Medical Disciplines and Geographical Areas, 2011. Graschew G, Roelofs TA, Eds. InTech, Rijeka, Croatia, p. 215-230. [Google Scholar]

39. Liu L, Wei $Q$, Alvarez X, Wang H, Du Y, Zhu H, Jiang $H$, Zhou J, Lam P, Zhang L, Lackner A, Qin C, Chen Z. Epithelial cells lining salivary gland ducts are early target cells of severe acute respiratory syndrome coronavirus infection in the upper respiratory tracts of rhesus macaques. J Virol. 2011 Apr;85(8):4025-30. [PubMed]
[Google Scholar]

40. Kampf G, Todt D, Pfaender S, Steinmann E. Persistence of coronaviruses on inanimate surfaces and its inactivation with biocidal agents. J Hosp Infect. 2020 Mar;104(3):246-51. [PubMed] [Google Scholar]

41. Chen J. Pathogenicity and Transmissibility of 2019-nCoV-A Quick Overview and Comparison with Other Emerging Viruses. Microbes Infect. 2020 Mar;22(2):69-71. [PubMed] [Google Scholar]

42. Cleveland JL, Gray SK, Harte JA, Robison VA, Moorman AC, Gooch BF. Transmission of blood-borne pathogens in US dental health care settings: 2016 update. J Am Dent Assoc. 2016 Sep;147(9):729-38. [PubMed] [Google Scholar]

43. Harrel SK, Molinari J. Aerosols and splatter in dentistry: a brief review of the literature and infection control implications. J Am Dent Assoc. 2004 Apr;135(4):42937. [PubMed] [Google Scholar]

44. Meng L, Hua F, Bian Z. Coronavirus disease 2019 (COVID-19): emerging and future challenges for dental and oral medicine. J Dent Res. 2020 May;99(5):481-7. [PubMed] [Google Scholar]

45. Ather A, Patel B, Ruparel NB, Diogenes A, Hargreaves KM. Coronavirus Disease 19 (COVID-19): implications for clinical dental care. J Endod. 2020 May;46(5):58495. [PubMed] [Google Scholar]

46. Ferioli M, Cisternino $C$, Leo V, Pisani L, Palange $P$, Nava S. Protecting healthcare workers from SARS-CoV-2 infection: practical indications. Eur Respir Rev. 2020 Apr;29(155):200068. [PubMed] [Google Scholar]

47. Centers for Disease Control and Prevention. Interim infection prevention and control recommendations for patients with suspected or confirmed coronavirus disease 2019 (COVID-19) in healthcare settings. (update April 13, 2020). Atlanta, GA: CDC, 2020. [Google Scholar]

48. Manocha S, Walley KR, Russell JA. Severe acute respiratory distress syndrome (SARS): a critical care perspective. Crit Care Med. 2003 Nov;31(11):2684-92. [PubMed] [Google Scholar]

49. Duan S-M, Zhao X-S, Wen R-F, Huang J-J, Pi G-H, Zhang S-X, Han J, Bi S-L, Ruan L, Dong X-P, SARS Research Team. Stability of SARS coronavirus in human specimens and environment and its sensitivity to heating and UV irradiation. Biomed Environ Sci. 2003 Sep;16(3):246-55. [PubMed] [Google Scholar]

50. ADA. What Constitutes a Dental Emergency? American Dental Association, Chicago, IL, USA. 2020.

51. Rabenau HF, Cinatl J, Morgenstern B, Bauer G, Preiser W, Doerr HW. Stability and inactivation of SARS coronavirus. Med Microbiol Immunol. 2005 Jan;194(12):1-6. [PubMed] [Google Scholar]

52. Kampf G, Kramer A. Epidemiologic background of hand hygiene and evaluation of the most important 
agents for scrubs and rubs. Clin Microbiol Rev. 2004 Oct;17(4):863-893. [PubMed] [Google Scholar]

53. Groupe V, Engle CC, Gaffney PE. Virucidal activity of representative antiinfective agents against influenza $A$ and vaccinia virus. Appl Microbiol. 1955 Nov;3:333-6. [PubMed] [Google Scholar]

54. Kampf G, Rudolf M, Labadie J-C, Barrett SP. Spectrum of antimicrobial activity and user acceptability of the hand disinfectant agent Sterillium Gel. J Hosp Infect. 2002 Oct;52:141-7. [PubMed] [Google Scholar]

55. Bond WXV, Favero MS, Petersen NJ, Ebert JW. Inactivation of hepatitis $B$ virus by intermediate to high-level disinfectant chemicals. J Clin Microbiol. 1983 Sep;18(3):535-8. [PubMed] [Google Scholar]

56. Kobayashi H, Tsuzuki M, Koshimizu K, Toyama H, Yoshihara N, Shikata T, Abe K, Mizuno K, Otomo N, Oda T. Susceptibility of hepatitis B virus to disinfectants or heat. J Clin Microbiol. 1984 Aug;20(2):214-6. [PubMed] [Google Scholar]

57. Payan C, Pivert A, Kampf G, Ramon C, Cottin J, Lemarie C. Assessment of new chemical disinfectants for HBV virucidal activity in a cell culture model. J Hosp Infect. 2004 Apr;56 Suppl 2:S58-63. [PubMed] [Google Scholar]

58. Martin LS, Meoougal JS, Loskoski SL. Disinfection and inactivation of the human T lymphotropic virus type III/lymphadenopathy associated virus. J Infect Dis. 1985 Aug;152(2):400-3. [PubMed] [Google Scholar]

59. Spire B, Barre-Sinoussi F, Montagnier L, Chermann JC. Inactivation of lymphadenopathy associated virus by chemical disinfectants. Lancet. 1984 Oct;2(8408):899901. [PubMed] [Google Scholar] 